\title{
In vitro antibacterial, antioxidant and cytotoxic activity of acetone leaf extracts of nine under-investigated Fabaceae tree species leads to potentially useful extracts in animal health and productivity
}

\author{
Jean P Dzoyem ${ }^{1,2}$, Lyndy J McGaw ${ }^{1}$ and Jacobus N Eloff ${ }^{1 *}$
}

\begin{abstract}
Background: The Fabaceae family is the second largest family of medicinal plants, containing more than 490 species which are being used as traditional medicine. The aim of this study was to determine the antioxidant and antibacterial activity as well as the cytotoxicity of acetone leaf extracts of nine tree species from the Fabaceae family that have not been investigated well previously for possible use in animal health and production.

Methods: The antibacterial activity was determined by a serial microdilution method against three Gram-positive and three Gram-negative bacteria. Antioxidant activity was determined using free-radical scavenging assays. The safety of the extracts was ascertained using the 3-(4,5-dimethylthiazol-2-yl)-2,5-diphenyltetrazolium bromide (MTT) assay on Vero African green monkey kidney cells.

Results: Six of the nine acetone extracts had significant antibacterial activity against at least one of the six bacterial species with (MIC $20-80 \mu \mathrm{g} / \mathrm{mL}$ ). The Crotalaria capensis extract had the highest activity against Salmonella typhimurium, followed by Indigofera cylindrica with MICs of $20 \mu \mathrm{g} / \mathrm{mL}$ and $40 \mu \mathrm{g} / \mathrm{mL}$ respectively. The Dalbergia nitidula extract had free radical scavenging capacity $\left(\mathrm{IC}_{50}\right.$ of $\left.9.31 \pm 2.14 \mathrm{\mu g} / \mathrm{mL}\right)$ close to that of the positive control Trolox in the DPPH assay. The Xylia torreana extract also had high activity $\left(\mathrm{IC}_{50}\right.$ of $\left.14.56 \pm 3.96 \mu \mathrm{g} / \mathrm{mL}\right)$ in the ABTS assay. There was a good correlation between antioxidant activity and total phenolic content $\left(R^{2}\right.$ values $\left.>0.8\right)$. The extracts had weak or no toxicity to Vero cells, compared to the positive control doxorubicin with the $L C_{50}$ varying from $10.70 \pm 3.47$ to $131.98 \pm$ $24.87 \mu \mathrm{g} / \mathrm{mL}$ at the concentrations tested.

Conclusion: Extracts of D. nitidula, X. torreana, C. capensis and I. cylindrica had a low cytotoxicity and high antimicrobial and/or antioxidant activity. These species are therefore promising candidates for the development of useful antimicrobial/antioxidant preparations with a low cytotoxicity that may be useful in promoting animal health and productivity.
\end{abstract}

Keywords: Antioxidant, Antimicrobial, Cytotoxicity, Efficacy, Fabaceae, Safety

\footnotetext{
* Correspondence: kobus.eloff@up.ac.za

'Phytomedicine Programme, Department of Paraclinical Sciences, Faculty of Veterinary Science, University of Pretoria, Private Bag X04, Onderstepoort 0110, Pretoria, South Africa

Full list of author information is available at the end of the article
} 


\section{Background}

Most of the potentially harmful effects of oxygen are due to the formation and activity of a number of chemical compounds known as reactive oxygen species. Many such reactive species are free radicals derived either from normal metabolic processes in the human body or from external sources [1]. Free radicals and peroxidative damage have been implicated in several human and animal pathological disorders, including inflammatory ailments and microbial infectious diseases [2]. The deleterious effects of the free radicals can be diminished by natural antioxidants available in plants. Among the various natural compounds extracted from plants that have demonstrated biological activities, many are receiving particular attention as radical scavengers [3]. Therefore, the discovery of novel antimicrobial agents from plants that also target free radicals with a low toxicity may be useful in the field of phytotherapy. Natural products present in higher plants are an important source of therapeutic agents and many research groups are currently screening different biological activities of plants [4]. Several studies have proven the antioxidant or radical scavenging properties of medicinal plant extract [5]. The Phytomedicine Programme of the University of Pretoria (www.up.ac. $\mathrm{za} / \mathrm{phyto}$ ) has contributed to this area by determining the antibacterial and antifungal activity of acetone leaf extracts of more than 500 tree species against 8 very important bacterial and fungal pathogens. Nine tree species belonging to the Fabaceae family, with very few or no previous pharmacological investigations reported were selected from the Phytomedicine plant database for in depth investigation.

The Fabaceae is the third largest family among the angiosperms after the Orchidaceae and Asteraceae, consisting of more than 700 genera and about 20000 species of trees, shrubs, vines, and herbs worldwide [6]. It is the second largest family of medicinal plants, containing over 490 species used as traditional medicine [7]. To the best of our knowledge, the plant species involved in this study are being screened for the first time, except Erythrina caffra Thunb., which has been reported to have antimicrobial activity [8]. Some of these species are used traditionally to combat infections (Table 1). In this study, in vitro antibacterial and antioxidant activities of the acetone leaf extracts of nine South African medicinal plants belonging to the Fabaceae family were investigated. Because plant material from nearly 290 species belonging to 100 genera of the Fabaceae has been reported to be toxic [7], the cytotoxicity was determined to ascertain the safety of the studied extracts.

Extracts with a good antimicrobial activity or good antioxidant activity and low toxicity may be useful in addressing animal health and productivity in aspects such as microbial infections, replacing antibiotic feed additives and treating infectious diarrhoea, a focus area of the Phytomedicine Programme.

\section{Methods}

\section{Plant material and extraction}

The leaves of plants were collected in the Pretoria National Botanical Garden in South Africa. The identity of the plant material was confirmed by the curator and voucher specimens were placed in the HGWJ Schweickerdt Herbarium of the University of Pretoria (PRU) (Table 1). Collected tree leaves were dried at room temperature in a well-ventilated room and ground to a fine powder in a Macsalab Mill (Model 2000 LAB Eriez). One gram of each plant was extracted in $10 \mathrm{~mL}$ of acetone, (technical grade, Merck) in a polyester centrifuge tube. The tube was vigorously shaken for $30 \mathrm{~min}$ on an orbital shaker, then centrifuged at $4000 \times \mathrm{g}$ for $10 \mathrm{~min}$ and the supernatant was filtered using Whatman No.1 filter paper before being transferred into pre-weighed glass containers. This was repeated thrice on the same plant material and the solvent was removed by evaporation under a stream of air in a fume hood at room temperature to produce the dried extract.

\section{Chemicals}

Sodium carbonate was obtained from Holpro Analytic, South Africa. Gentamicin was purchased from Virbac, South Africa. Fetal calf serum (FCS) and minimum essential medium (MEM with L-glutamine) was provided by Highveld Biological, Johannesburg, South Africa. Phosphate buffered saline (PBS) and trypsin were purchased from Whitehead Scientific, South Africa. Doxorubicin was obtained from Pfizer, South Africa. Dimethyl sulfoxide (DMSO), 2,2'-Azino-bis (3-ethylbenzothiazoline6-sulphonic acid) diamonium salt (ABTS), 2,2-diphe nyl-1-picrylhydrazyl (DPPH), 3-4,5-dimethylthiazol-2-yl)2,5-diphenyltetrazolium bromide (MTT), p-iodonitrotetrazolium violet (INT), Folin-Ciocalteu reagent, gallic acid, 2,5,7,8-tetramethylchroman carboxylic acid (Trolox) and potassium persulfate were purchased from Sigma-Aldrich St. Louis, MO, USA. Müller Hinton agar and broth were from Sigma-Aldrich, India.

\section{Antibacterial assay}

The antimicrobial activity of extracts dissolved in acetone was determined against six bacterial strains: three Gram-positive bacteria (Staphylococcus aureus ATCC 29213, Enterococcus faecalis ATCC 29212, Bacillus cereus ATCC 14579) and three Gram-negative bacteria (Escherichia coli ATCC 25922, Pseudomonas aeruginosa ATCC 27853 and Salmonella typhimurium ATCC 14028). This activity was evaluated by the determining the minimal inhibitory concentration (MIC) using a rapid broth 


\section{Table 1 Characteristics of the nine plants of Fabaceae family investigated}

\begin{tabular}{|c|c|c|c|c|c|}
\hline Name of plant & Common names & Synonyms & Parts used & Traditional or other uses & Voucher number \\
\hline $\begin{array}{l}\text { Baphia racemosa } \\
\text { (Hochst) Baker. }\end{array}$ & $\begin{array}{l}\text { Violet pea, Natal camwood (Eng.); } \\
\text { boskamhout (Afr.); Tshuphu } \\
\text { (isiXhosa); Fithi (Zulu) }\end{array}$ & Bracteolaria racemosa Hochst. & Leaves & $\begin{array}{l}\text { Source of food for larvae of the blue-spotted } \\
\text { charaxes. Parrots feed on young seeds [9]. }\end{array}$ & PMDN 397 \\
\hline Crotalaria capensis Jacq. & $\begin{array}{l}\text { Cape rattle-pod, Cape laburnum } \\
\text { (Eng.); Kaapse klapperpeul (Afr.); } \\
\text { Bukheshezane (Zulu) }\end{array}$ & - & Flowers & Decorative horticultural value [10]. & PMDN 318 \\
\hline Dalbergia nitidula Baker & $\begin{array}{l}\text { Glossy flat-bean (English) Mudima } \\
\text { (Shona) Murima (Shona) } \\
\text { Purple-wood dalbergia (English) }\end{array}$ & Dalbergia dekindtiana Harms & Roots & $\begin{array}{l}\text { For some species in this genus, a paste of } \\
\text { charred and powdered stems mixed with } \\
\text { water is used for sore mouths in infants [11]. }\end{array}$ & PMDN 367 \\
\hline Erythrina caffra Thunb. & $\begin{array}{l}\text { Coast coral tree (Eng.); kuskoraalboom } \\
\text { (Afr.); umsinsi (Zulu); umsintsi (Xhosa) }\end{array}$ & Erythrina viarium Tod. & Bark, leaves, roots & $\begin{array}{l}\text { Sores, tuberculosis, respiratory infections, } \\
\text { wounds, eardrops for earache, sprains [11]. }\end{array}$ & PMDN 280 \\
\hline Indigofera cylindrica & $\begin{array}{l}\text { Natal Camwood (Eng.) Natal } \\
\text { Camwood }\end{array}$ & $\begin{array}{l}\text { Indigofera frutescens Indigofera } \\
\text { jucunda Schrire }\end{array}$ & - & $\begin{array}{l}\text { Plants of the genus are used for infertility, } \\
\text { menstrual cramps, toothbrushes, mouthwash [12]. }\end{array}$ & PMDN 178 \\
\hline $\begin{array}{l}\text { Lonchocarpus nelsii } \\
\text { (Schinz) Heering \& Grimme }\end{array}$ & $\begin{array}{l}\text { Apple-leaf lance-pod, Kalahari } \\
\text { apple-leaf, Kalahari lance-pod (Eng.) }\end{array}$ & $\begin{array}{l}\text { Dalbergia nelsii, Philenoptera nelsii } \\
\text { (Schinz) Schrire }\end{array}$ & - & $\begin{array}{l}\text { Plants of the genus are used as a laxative, for } \\
\text { treating convulsion in infants, and for minor skin } \\
\text { trouble [13]. }\end{array}$ & PMDN 612 \\
\hline $\begin{array}{l}\text { Podalyria calyptrata } \\
\text { (Retz.) Willd. }\end{array}$ & $\begin{array}{l}\text { Sweetpea bush, large pink keurtjie, } \\
\text { water blossom-pea (Eng.); keur, } \\
\text { keurtjie, keurblom, ertjiebos, } \\
\text { waterkeurtjie (Afr.) }\end{array}$ & $\begin{array}{l}\text { Podalyria kunthii Walp., Podalyria } \\
\text { lanceolata (E. Mey.) Benth. }\end{array}$ & - & $\begin{array}{l}\text { Purely decorative as no records of other uses } \\
\text { could be traced. }\end{array}$ & PMDN 759 \\
\hline Virgilia divaricata Adamson. & Blossom tree (Eng.); keurboom (Afr.) & - & - & $\begin{array}{l}\text { Transparent gum exudate from the bark is used } \\
\text { as a substitute for starch [14]. }\end{array}$ & PMDN 192 \\
\hline Xylia torreana Brenan & Hairy sand ash, Zambezi ash (Eng.) & Xylia africana sensu Torre & - & No information on tradition use found & PMDN159 \\
\hline
\end{tabular}


microdilution technique with $\mathrm{p}$-iodonitrotetrazolium violet (INT) as growth indicator as developed by Eloff [15]. The samples were serially diluted to provide a final concentration range of 2.5 to $0.02 \mathrm{mg} / \mathrm{mL}$. In addition to $\mathrm{MIC}$, the total activity was calculated as the total mass in mg extracted from $1 \mathrm{~g}$ of plant material divided by the $\mathrm{MIC}$ value $(\mathrm{mg} / \mathrm{mL})$. The total activity in $\mathrm{ml} / \mathrm{g}$ indicates the volume to which the extract derived from $1 \mathrm{~g}$ of plant material can be diluted and still inhibits the growth of the microorganism [16].

\section{Antioxidant assays \\ Total phenolic content determination}

The total phenolic content was determined colorimetrically using a Folin-Ciocalteu 96-well microplate assay developed by Zhang et al [17]. The total phenolic content was calculated from the linear equation of a standard curve prepared with gallic acid, and expressed as gallic acid equivalent (GAE) per g of extract.

\section{ABTS radical assay}

The ABTS radical scavenging capacity of the samples was measured with modifications of the 96-well microtitre plate method described by Re et al. [18]. Trolox and ascorbic acid were used as positive controls, methanol as negative control and extract without ABTS as blank. The percentage of ABTS + inhibition was calculated using the formula: Scavenging capacity $(\%)=100-[(\mathrm{ab}-$ sorbance of sample - absorbance of sample blank) $\times 100$ / (absorbance of control) - (absorbance of control blank)]. The $\mathrm{IC}_{50}$ values were calculated from the graph plotted as inhibition percentage against the concentration.

\section{DPPH assay}

The DPPH radical-scavenging activity was determined using the method proposed by Brand-Williams et al. [19]. Ascorbic acid and Trolox were used as positive controls, methanol as negative control and extract without DPPH as blank. Results were expressed as percentage reduction of the initial DPPH absorption in relation to the control. The concentration of extract that reduced the $\mathrm{DPPH}$ colour by $50 \%\left(\mathrm{IC}_{50}\right)$ was determined as for ABTS + .

\section{Cytotoxic activity}

The cytotoxicity of the acetone extracts against Vero monkey kidney cells was assessed by the MTT reduction assay as previously described [20] with slight modifications. Cells were seeded at a density of $1 \times 10^{5}$ cells $/ \mathrm{ml}$ $(100 \mu \mathrm{l})$ in 96 -well microtitre plates and incubated at $37^{\circ} \mathrm{C}$ and $5 \% \mathrm{CO}_{2}$ in a humidified environment. After $24 \mathrm{~h}$ incubation, extracts $(100 \mu \mathrm{l})$ at varying final concentrations were added to the wells containing cells. Doxorubicin was used as a positive reference. A suitable blank control with equivalent concentrations of acetone was also included and the plates were further incubated for $48 \mathrm{~h}$ in a $\mathrm{CO}_{2}$ incubator. Thereafter, the medium in each well was aspirated from the cells, which were then washed with PBS, and finally fresh medium $(200 \mu \mathrm{l})$ was added to each well. Then, $30 \mu \mathrm{l}$ of MTT $(5 \mathrm{mg} / \mathrm{ml}$ in PBS) was added to each well and the plates were incubated at $37^{\circ} \mathrm{C}$ for $4 \mathrm{~h}$. The medium was aspirated from the wells and DMSO was added to solubilize the formed formazan crystals. The absorbance was measured on a BioTek Synergy microplate reader at $570 \mathrm{~nm}$. Cell growth inhibition for each extract was expressed in terms of $\mathrm{LC}_{50}$ values, defined as the concentration that caused $50 \%$ of inhibition of cell viability. The selectivity index (SI) values were calculated by dividing cytotoxicity $\mathrm{LC}_{50}$ values by the MIC values $\left(\mathrm{SI}=\mathrm{LC}_{50} / \mathrm{MIC}\right)$. Tests were carried out in quadruplicate and each experiment was repeated thrice.

\section{Statistical analysis}

All experiments were conducted in triplicate and values expressed as mean \pm standard deviation. For the MIC values, re-evaluation of the growth inhibition was conducted where variation within the three experiments was noticed. Statistical analysis was performed using one way ANOVA and results were compared using the Fisher's least significant difference (LSD) at a 5\% significance level.

\section{Results and discussion}

\section{Antimicrobial activity}

The MIC values of the leaf extracts of 9 species of the Fabaceae family are presented in Table 2. Extracts had a broad spectrum of activity against all bacterial strains. Crude extracts with an $\mathrm{MIC}<100 \mu \mathrm{g} / \mathrm{mL}$ are usually considered as significantly active [21] and therefore could be regarded as promising candidates for further studies. In this study, six of the nine extracts investigated had significant activity, including extracts of C. capensis against S. typhimurium followed by the extract of $I$. cylindrica with respective MICs of 20 and $40 \mu \mathrm{g} / \mathrm{mL}$. Significant activities were also recorded (MIC of $80 \mu \mathrm{g} / \mathrm{ml}$ ) with extracts of C. capensis, E. caffra and L. nelsii against E. faecalis. D. nitidula and V. divaricata had similar activity against $B$. cereus. Olajuyigbe and Afolayan previously reported moderate antibacterial activity of the ethanolic extract from $E$. caffra bark against two Gram positive (E. faecalis, S. aureus) and two Gram negative (E. coli, $P$. aeruginosa) bacteria (MICs ranged from 156.6 to $625 \mu \mathrm{g} / \mathrm{mL}$ ) [8].

A significant antimicrobial activity of an extract is a highly promising result, since an extract consists of a mixture of compounds. A bioassay-guided fractionation might lead to the isolation of active ingredients with an 
Table 2 Minimal inhibitory concentration (MIC in $\mu \mathrm{g} / \mathrm{mL}$ ) and total activity (TA in $\mathrm{mL} / \mathrm{g}$ ) of acetone leaf extracts from nine plants of the Fabaceae family against bacterial strains

\begin{tabular}{|c|c|c|c|c|c|c|c|c|c|c|c|c|c|c|}
\hline \multirow[t]{3}{*}{ Plant name } & \multirow{3}{*}{$\begin{array}{c}\text { Extraction } \\
\text { yield (\%) }\end{array}$} & \multirow[t]{3}{*}{ ME (mg) } & \multicolumn{12}{|c|}{ Microorganisms } \\
\hline & & & \multicolumn{2}{|c|}{ S. aureus } & \multicolumn{2}{|c|}{ E. faecalis } & \multicolumn{2}{|c|}{ B. cereus } & \multicolumn{2}{|c|}{ E. coli } & \multicolumn{2}{|c|}{ P. aeruginosa } & \multicolumn{2}{|c|}{ S. typhimurium } \\
\hline & & & MIC & TA & MIC & TA & MIC & TA & $\overline{\mathrm{MIC}}$ & TA & MIC & TA & MIC & TA \\
\hline Baphia racemosa & 3.7 & 37 & 310 & 119.35 & 160 & 231.25 & 625 & 59.20 & 625 & 59.20 & $>1000$ & $<37$ & 625 & 59.20 \\
\hline Crotalaria capensis & 4.6 & 46 & 625 & 73.60 & 80 & 575 & 310 & 148.39 & 625 & 73.60 & 625 & 73.60 & 20 & 2300 \\
\hline Dalbergia nitidula & 4.2 & 42 & 160 & 262.5 & 160 & 262.5 & 80 & 525 & 160 & 262.5 & 310 & 135.48 & 160 & 262.5 \\
\hline Erythrina caffra & 3.9 & 39 & $>1000$ & $<39$ & 80 & 487.5 & 310 & 125.81 & 160 & 243.75 & 160 & 243.75 & 310 & 125.81 \\
\hline Indigofera cylindrica & 1.9 & 19 & 625 & 30.40 & 310 & 61.29 & 160 & 118.75 & 310 & 61.29 & 310 & 61.29 & 40 & 475 \\
\hline Lonchocarpus nelsii & 0.9 & 9 & $>1000$ & $<9$ & 80 & 112.5 & 625 & 14.40 & 625 & 14.40 & $>1000$ & $<9$ & 80 & 112.5 \\
\hline Podalyria calyptrata & 3.4 & 34 & $>1000$ & $<34$ & 625 & 54.40 & $>1000$ & $<34$ & 310 & 109.68 & $>1000$ & $<34$ & 160 & 212.5 \\
\hline Virgilia divaricata & 8.9 & 89 & 310 & 287.1 & 625 & 142.40 & 80 & 1112.5 & 310 & 287.1 & $>1000$ & $<89$ & 80 & 1112.5 \\
\hline Xylia torreana & 1.2 & 12 & 310 & 38.71 & 160 & 75 & 160 & 75 & 310 & 38.71 & 310 & 38.71 & 160 & 75 \\
\hline Gentamicin & nd & nd & 0.2 & nd & 0.2 & nd & 0.8 & nd & 0.4 & nd & 0.2 & nd & 1.56 & nd \\
\hline
\end{tabular}

Mass in mg extracted from $1 \mathrm{~g}(\mathrm{ME})$.

Values in bold indicate MICs lower than $100 \mu \mathrm{g} / \mathrm{mL}$ and total activity higher than $1000 \mathrm{ml} / \mathrm{g}$, nd: not determined.

activity better than that of standard antibiotics. However, low activity was noticed with all the extracts against the Gram-positive $S$. aureus and two Gram-negative bacteria, namely $E$. coli and $P$. aeruginosa. The significant activity of extracts against Gram-negative bacteria (including $S$. typhimurium) which are often resistant to antimicrobial agents compared to Gram-positive [22], could be explained by the possibility that the active compounds may act by inhibiting bacterial growth without necessarily penetrating into the bacterial cell itself. Although an interesting activity was found with the extracts of $C$. capensis against $S$. typhimurium, the calculated total activity was lower $(475 \mathrm{~mL} / \mathrm{g})$ compared to that of the I. cylindrica extract $(2300 \mathrm{~mL} / \mathrm{g})$. Therefore, the extract of I. cylindrica appears to be the most promising antimicrobial candidate for isolation of biologically active compounds as well as for the rational use of the plant extract in primary health care by rural communities for human or animal health.

\section{Antioxidant activity and total phenolic content}

The antioxidant capacity expressed as $\mathrm{IC}_{50}$ value and total phenolic content of all extracts are shown in Table 3. All the extracts had moderate to potent antioxidant activity $\mathrm{The} \mathrm{IC}_{50}$ values occurred in the range of $9.31 \pm 2.14$ to $271.58 \pm 51.96 \mu \mathrm{g} / \mathrm{mL}$ in the $\mathrm{DPPH}$ assay, and $14.56 \pm 3.96$ to $207.09 \pm 70.75 \mu \mathrm{g} / \mathrm{mL}$ in the ABTS radical assay. The use of at least two different assays in evaluating antioxidant activity of plant extracts has been recommended by Moon and Shibamoto [23]. Significant variations $(\mathrm{p}<0.05)$ were observed between the extracts tested. With $\mathrm{IC}_{50}$ of $9.31 \pm 2.14 \mu \mathrm{g} / \mathrm{mL}$, extracts from $D$. nitidula had free radical scavenging capacity close to that of the positive control Trolox $\left(\mathrm{IC}_{50}\right.$ of $\left.9.71 \pm 2.23 \mu \mathrm{g} / \mathrm{mL}\right)$ in the DPPH assay. A similar result was obtained with the Xylia torreana $\left(\mathrm{IC}_{50}\right.$ of $14.56 \pm 3.96 \mu \mathrm{g} / \mathrm{mL}$ ) extract in the ABTS assay where Trolox had an $\mathrm{IC}_{50}$ of $12.48 \pm 3.7 \mu \mathrm{g} / \mathrm{mL}$. These results indicate that these two extracts could be a potential source of natural antioxidants.

The total phenolic contents (TPC) of the extracts were in the range of $0.12 \pm 0.1$ to $14.39 \pm 0.62 \mathrm{mg} \mathrm{GAE} / \mathrm{g}$. According to Makkar [24] the TPC of an extract amounting

Table 3 Antioxidant activity and total phenolic content (TPC) of acetone extracts from nine plants of the Fabaceae family

\begin{tabular}{|c|c|c|c|}
\hline Plant name & $\begin{array}{c}\text { DPPH IC } \mathrm{IC}_{50}(\mu \mathrm{g} / \\
\mathrm{mL})\end{array}$ & $\begin{array}{c}\text { ABTS } I C_{50}(\mu \mathrm{g} / \\
\mathrm{mL})\end{array}$ & $\begin{array}{c}\text { TPC }(\mathbf{m g} \\
\text { GAE/g) }\end{array}$ \\
\hline Baphia racemosa & $210.69 \pm 65.48^{a}$ & $195.10 \pm 54.68^{a}$ & $0.12 \pm 0.1^{a}$ \\
\hline $\begin{array}{l}\text { Crotalaria } \\
\text { capensis }\end{array}$ & $195.26 \pm 30.64^{a}$ & $207.09 \pm 70.75^{a}$ & $2.21 \pm 0.95^{b}$ \\
\hline Erythrina caffra & $268.6 \pm 29.69^{a}$ & $173.28 \pm 43.04^{\mathrm{a}}$ & $3.29 \pm 1.38^{c}$ \\
\hline $\begin{array}{l}\text { Lonchocarpus } \\
\text { nelsii }\end{array}$ & $247.70 \pm 66.47^{\mathrm{a}}$ & $134.64 \pm 16.49^{a}$ & $1.51 \pm 0.74^{b}$ \\
\hline Virgilia divaricata & $271.58 \pm 51.96^{\mathrm{a}}$ & $150.57 \pm 19.23^{a}$ & $0.86 \pm 0.53^{d}$ \\
\hline $\begin{array}{l}\text { Indigofera } \\
\text { cylindrica }\end{array}$ & $22.31 \pm 9.92^{b}$ & $41.39 \pm 15.74^{b}$ & $8.94 \pm 1.52^{\mathrm{e}}$ \\
\hline Xylia torreana & $16.90 \pm 5.45^{b}$ & $14.56 \pm 3.96^{c}$ & $12.05 \pm 1.23^{f}$ \\
\hline $\begin{array}{l}\text { Podalyria } \\
\text { calyptrata }\end{array}$ & $35.21 \pm 3.46^{c}$ & $36.66 \pm 3.59^{b}$ & $7.89 \pm 1.48^{e}$ \\
\hline $\begin{array}{l}\text { Dalbergia } \\
\text { nitidula }\end{array}$ & $9.31 \pm 2.14^{d}$ & $21.30 \pm 5.07^{d}$ & $14.39 \pm 0.62^{9}$ \\
\hline Trolox & $9.71 \pm 2.23^{d}$ & $12.48 \pm 3.7^{c}$ & nd \\
\hline Ascorbic acid & $2.44 \pm 0.9^{e}$ & $3.14 \pm 1.07^{\mathrm{e}}$ & nd \\
\hline
\end{tabular}

Values in bold indicate MICs lower than $100 \mu \mathrm{g} / \mathrm{mL}$ and total activity higher than $1000 \mathrm{ml} / \mathrm{g}$.

$n=3$, means values within a column with different superscript letters are significantly different at $\mathrm{p}<0.05 ; \mathrm{mg}$ GAE/g: $\mathrm{mg}$ of gallic acid equivalent per $\mathrm{g}$ of dry plant material. 


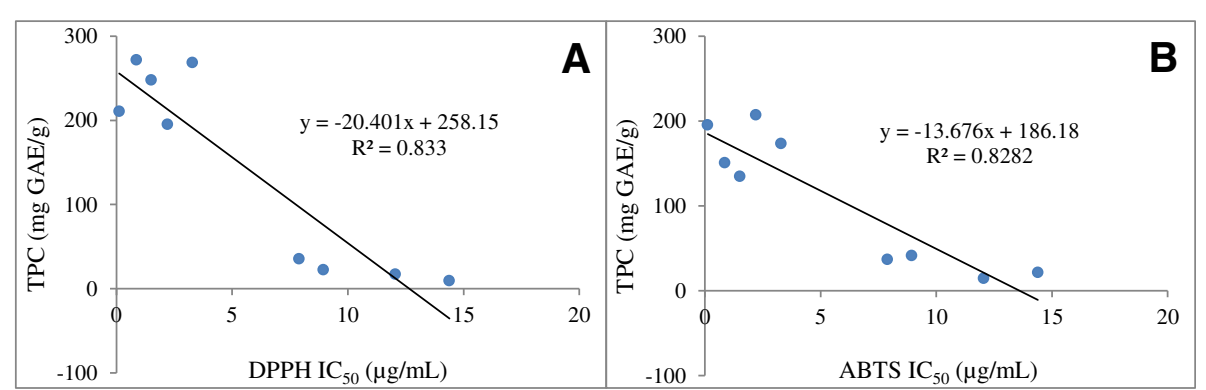

Figure 1 Correlation between antioxidant capacity and total phenolic content of nine species from the Fabaceae family. Antioxidant capacity was measured by DPPH assay (A) and ABTS radical assay (B). GAE: gallic acid equivalent.

to $5 \mathrm{mg} \mathrm{GAE} / \mathrm{g}$ is considered to be significant and could have a beneficial antioxidant efficacy. Taking into account this cut-off, extracts of D. nitidula, I. cylindrica, $P$. calyptrata and $X$. torreana contain significant amounts of phenols. The TPC correlated well with the respective antioxidative activity of extracts (Figure 1). Good correlation was found between the $\mathrm{TPC}$ and $\mathrm{IC}_{50}$ values for both DPPH and ABTS $\left(R^{2}>0.833\right.$ and $R^{2}>0.828$ respectively). Polyphenols have been reported to be responsible for the antioxidant activity in plant extracts [25].

The high levels of TPC observed with the extract of D. nitidula and I. cylindrica could be related to their good antimicrobial activity because many phenolic compounds have antimicrobial activity and antioxidant activity [26]. Although no in vivo experiments have been done, the good antioxidant activity of acetone extracts combined with good antibacterial activity indicates that these extracts may fulfill a dual role if used therapeutically.

In the case of C. capensis, E. caffra, L. nelsii and $V$. divaricata the good antibacterial activity was apparently not due to the presence of phenolics. Many secondary metabolites other than phenolic compounds are well known for their antimicrobial activities [27].

\section{Cytotoxic activity}

The cytotoxicity was determined using an in vitro assay with Vero monkey kidney cells. The $\mathrm{LC}_{50}$ and the selectivity index (SI) values were calculated (Table 4). The $\mathrm{LC}_{50}$ values ranged from $10.70 \pm 3.47$ to $131.98 \pm 24.87 \mu \mathrm{g} /$ $\mathrm{mL}$ while the SI ranged from 0.003 to 8.25 . Extracts of $P$. calyptrata had the highest $\mathrm{LC}_{50}$ (lowest toxicity) of $131.98 \pm 24.87 \mu \mathrm{g} / \mathrm{mL}$. B. racemosa had an $\mathrm{LC}_{50}$ of 10.70 $\pm 3.47 \mu \mathrm{g} / \mathrm{mL}$, which is relatively cytotoxic. Our results indicated that all the plant extracts investigated were less toxic to Vero cells than the positive control, doxorubicin. Apart from B. racemosa and E. caffra, all extracts had $\mathrm{LC}_{50}$ values greater than $30 \mu \mathrm{g} / \mathrm{mL}$.

In addition to ascertaining the likely safety of plant extracts for their potential use, standard cell-based toxicity assays are also performed in vitro at an early stage of the drug development process in order to remove high-risk materials [28]. Moreover, this helps to ensure that the biological activity of the plant extract is not due to a general

Table 4 Cytotoxicity of acetone leaf extracts from nine species of the Fabaceae family on Vero monkey kidney cells and their selectivity index (SI) against bacterial strains

\begin{tabular}{|c|c|c|c|c|c|c|c|}
\hline \multirow[t]{2}{*}{ Plant name } & \multirow[t]{2}{*}{$I C_{50}(\mu \mathrm{g} / \mathrm{ml})$} & \multicolumn{6}{|c|}{ Selectivity index (LC $\left.{ }_{50} / \mathrm{MIC}\right)$} \\
\hline & & $S A$ & $E F$ & $E C$ & $P A$ & $B C$ & $S T$ \\
\hline Podalyria calyptrata & $131.98 \pm 24.87^{a}$ & $<0.1$ & 0.21 & 0.43 & $<0.3$ & $<0.1$ & 0.82 \\
\hline Xylia torreana & $82.51 \pm 9.46^{b}$ & 0.27 & 0.52 & 0.27 & 0.27 & 0.52 & 0.52 \\
\hline Lonchocarpus nelsii & $81.09 \pm 7.18^{b}$ & $<0.1$ & 1.01 & 0.13 & $<0.1$ & 0.13 & 1.01 \\
\hline Indigofera cylindrica & $77.59 \pm 6.10^{b}$ & 0.13 & 0.25 & 0.25 & 0.25 & 0.48 & 1,94 \\
\hline Dalbergia nitidula & $51.28 \pm 11.47^{c}$ & 0.32 & 0.32 & 0.32 & 0.17 & 0.64 & 0.32 \\
\hline Crotalaria capensis & $45.47 \pm 10.48^{c}$ & 0.07 & 0.57 & 0.07 & 0.07 & 0.15 & 2.27 \\
\hline Virgilia divaricata & $30.08 \pm 4.96^{c}$ & 0.1 & 0.05 & 0.1 & $<0.1$ & 0.38 & 0.38 \\
\hline Erythrina caffra & $19.93 \pm 2.20^{d}$ & $<0.1$ & 0.25 & 0.12 & 0.12 & 0.06 & 0.06 \\
\hline Baphia racemosa & $10.7 \pm 3.47^{e}$ & 0.03 & 0.07 & 0.02 & $<0.1$ & 0.02 & 0.02 \\
\hline Doxorubicin & $2.29 \pm 1.04^{f}$ & nd & nd & nd & nd & nd & nd \\
\hline
\end{tabular}

For $\mathrm{IC}_{50}, \mathrm{n}=3$, means values with different superscript letters are significantly different at $\mathrm{p}<0.05$; nd: not determined. In bold are interesting results with SI value >1. SA: Staphylococcus aureus, EF: Enterococcus faecalis, BC: Bacillus cereus, EC: Escherichia coli, PA: Pseudomonas aeruginosa, ST: Salmonella typhimurium. 
metabolic toxic effect. Extracts of C. capensis and L. nelsii had SI values of 2.27 and 1.01 respectively. The higher the selectivity index is for a crude extract the more likely it is that the activity is not due to a general metabolic toxin [29]. Although elimination of toxic components by manipulation of the extract may yield more suitable antibacterial extracts [30] selection of an extract with a high selectivity index increases the potential that a useful herbal medicine can be produced.

\section{Conclusion}

Acetone leaf extracts of $D$. nitidula, X. torreana, $C$. capensis and I. cylindrica had a relatively low cytotoxicity and a high antibacterial and/or antioxidant activity. Thus, these plant species could be considered as potential candidates for the development of novel antimicrobial formulations with reduced toxicity that can be used to promote animal health and productivity [31], as well as for further studies to isolate the active compounds [32]. These aspects are being followed up with some plant species in the Phytomedicine Programme.

\section{Competing interests}

The authors declare that they have no competing interests.

\section{Authors' contributions}

JPD performed experiments and wrote the first draft of manuscript. LJM supervised the work and revised the manuscript; JNE initiated the project and revised the final manuscript. All authors read and approved the final manuscript.

\section{Acknowledgments}

The University of Pretoria provided a postdoctoral fellowship to JPD. The National Research Foundation (NRF) and Medical Research Council (MRC) provided funding to support this study.

\section{Author details}

'Phytomedicine Programme, Department of Paraclinical Sciences, Faculty of Veterinary Science, University of Pretoria, Private Bag X04, Onderstepoort 0110, Pretoria, South Africa. ${ }^{2}$ Present address: Department of Biochemistry, Faculty of Science, University of Dschang, P.O. Box 67, Dschang, Cameroon.

Received: 28 October 2013 Accepted: 29 April 2014

Published: 5 May 2014

\section{References}

1. Lobo V, Patil A, Phatak A, Chandra N: Free radicals, antioxidants and functional foods: impact on human health. Pharmacogn Rev 2010, 4(8):118-126.

2. Alviano DS, Alviano CS: Plant extracts: Search for new alternatives to treat microbial diseases. Curr Pharm Biotechnol 2009, 10(1):106-121.

3. Baratta MT, Dorman HJD, Deans SG, Biondi DM, Ruberto G: Chemical composition, antimicrobial and antioxidative activity of laurel, sage, rosemary, oregano and coriander essential oils. J Essent Oil Res 1998, 10(6):618-627

4. Kuete V, Efferth T: Cameroonian medicinal plants: pharmacology and derived natural products. Front Pharmacol 2010, 1:123-123.

5. Atawodi SE: Antioxidant potential of African medicinal plants. Afr J Biotechnol 2005, 4(2):128-133.

6. Stevens PF: Onwards Angiosperm Phylogeny Website 2001. Version 12 2012, http://www.mobot.org/MOBOT/research/APweb/

7. Gao T, Yao H, Song J, Liu C, Zhu Y, Ma X, Pang X, Xu H, Chen S: Identification of medicinal plants in the family Fabaceae using a potential DNA barcode ITS2. J Ethnopharmacol 2010, 130(1):116-121.
8. Olajuyigbe $\mathrm{OO}$, Afolayan AJ: In vitro antibacterial and time-kill evaluation of the Erythrina caffra Thunb. extract against bacteria associated with diarrhoea. Sci World J 2012, 2012:738314.

9. Van Wyk AE, Van Wyk P: Field Guide to Trees of Southern Africa. Cape Town: Random House Struik (Pty.); 1997.

10. Pooley E: The Complete Field Guide to Trees of Natal, Zululand and Transkei. Durban, South Africa: Natal Flora Publications Trust; 1993.

11. Hutchings A, Scott AH, Lewis G, Cunningham AB: Zulu Medicinal Plants: An Inventory. Pietermaritzburg, South Africa: University of Natal Press; 1996.

12. Kirtikar KR: Indian Medicinal Plants. Allahabad: Leader Press; 1993.

13. Ogbeide ON, Parvez M: A simple colorimetric quantification of flavonoids in the flowers of Lonchocarpus cyanescens genus - Lonchocarpus. Plant Foods Hum Nutr 1991, 41(3):233-239.

14. Goldblatt P, Manning J: Cape plants. A conspectus of the Cape flora of South Africa, National Botanical Institute, Pretoria \& Missouri Botanical Garden. 2000

15. Eloff JN: A sensitive and quick microplate method to determine the minimal inhibitory concentration of plant extracts for bacteria. Planta Med 1998, 64(8):711-713.

16. Eloff JN: On expressing the antibacterial activity of plant extracts - A small first step in applying scientific knowledge to rural primary health care. S Afr J Sci 2000, 96(3):116-118.

17. Zhang Q, Zhang J, Shen J, Silva A, Dennis DA, Barrow CJ: A simple 96-well microplate method for estimation of total polyphenol content in seaweeds. J Appl Phycol 2006, 18(3-5):445-450.

18. Re R, Pellegrini N, Proteggente A, Pannala A, Yang M, Rice-Evans C: Antioxidant activity applying an improved ABTS radical cation decolorization assay. Free Radic Biol Med 1999, 26(9-10):1231-1237.

19. Brand-Williams W, Cuveleir ME, Berset C: Use of a free radical method to evaluate antioxidant activity. LWT-Food Sci Technol 1995, 28(1):25-30.

20. Mosmann T: Rapid colorimetric assay for cellular growth and survival - application to proliferation and cytotoxicity assays. I Immunol Methods 1983, 65(1-2):55-63.

21. Eloff JN: Quantification the bioactivity of plant extracts during screening and bioassay guided fractionation. Phytomedicine 2004, 11(4):370-371.

22. Nikaido H: Antibiotic resistance caused by Gram-negative multidrug efflux pumps. Clin Infect Dis 1998, 27(Suppl 1):S32-S41.

23. Moon JK, Shibamoto T: Antioxidant assays for plant and food components. J Agric Food Chem 2009, 57:1655-1666.

24. Makkar HPS: Quantification of Tannins in Tree and Shrub Foliage: A Laboratory Manual. Dordrecht: Kluwer Academic Publishers; 2003.

25. Piluzza G, Bullitta S: Correlations between phenolic content and antioxidant properties in twenty-four plant species of traditional ethnoveterinary use in the Mediterranean area. Pharm Biol 2011, 49(3):240-247.

26. Mulaudzi RB, Ndhlala AR, Kulkarni MG, Finnie JF, Van Staden J: Antimicrobial properties and phenolic contents of medicinal plants used by the Venda people for conditions related to venereal diseases. J Ethnopharmacol 2011, 135(2):330-337.

27. Cowan MM: Plant products as antimicrobial agents. Clin Microbiol Rev 1999, 12(4):564-582.

28. Omar NS, Kannan TP, Ismail AR, Abdullah SF, Samsudin AR, Hamid SSA: In vitro cytotoxic evaluation of processed natural coral in human osteoblasts. Int J Toxicol 2011, 30(4):443-451.

29. Cho-Ngwa F, Abongwa M, Ngemenya MN, Nyongbela KD: Selective activity of extracts of Margaritaria discoidea and Homalium africanum on Onchocerca ochengi. BMC Complement Altern Med 2010, 10:62.

30. Eloff JN, Famakin JO, Katerere DRP: Combretum woodii (Combretaceae) leaf extracts have high activity against Gram-negative and Gram-positive bacteria. Afr J Biotechnol 2005, 4:1161-1166.

31. Suleiman MM, Duncan JN, Eloff JN, Naidoo V: A controlled study to determine the efficacy of Loxostylis alata (Anacardiaceae) in the treatment of aspergillosus in a chicken (Gallus domesticus) model in comparison to ketoconazole. BMC Vet Res 2012, 8:210

32. Eloff JN, Katerere DR, McGaw $\sqcup$ : The biological activity and chemistry of the southern African Combretaceae. J Ethnopharmacol 2008, 119:686-699.

\section{doi:10.1186/1472-6882-14-147}

Cite this article as: Dzoyem et al:: In vitro antibacterial, antioxidant and cytotoxic activity of acetone leaf extracts of nine under-investigated Fabaceae tree species leads to potentially useful extracts in animal healthand productivity. BMC Complementary and Alternative Medicine 2014 14:147. 